University of South Carolina

Scholar Commons

$12-1993$

\title{
Seismic evidence for blind thrusting of the northwestern flank of the Venezuelan Andes
}

Bruno De Toni

James N. Kellogg

University of South Carolina - Columbia, kellogg@geol.sc.edu

Follow this and additional works at: https://scholarcommons.sc.edu/geol_facpub

Part of the Earth Sciences Commons

\section{Publication Info}

Published in Tectonics, Volume 12, Issue 6, 1993, pages 1393-1409.

De Toni, B. \& Kellogg, J. N. (1993). Seismic evidence for blind thrusting of the northwestern flank of the Venezuelan Andes. Tectonics, 12 (6), 1393-1409.

(C)Tectonics 1993, American Geophysical Union

This Article is brought to you by the Earth, Ocean and Environment, School of the at Scholar Commons. It has been accepted for inclusion in Faculty Publications by an authorized administrator of Scholar Commons. For more information, please contact digres@mailbox.sc.edu. 


\section{SEISMIC EVIDENCE FOR BLIND THRUSTING OF THE NORTHWESTERN FLANK OF THE VENEZUELAN ANDES}

Bruno De Toni

INTEVEP, S.A., Caracas, Venezuela

James Kellogg

Department of Geological Sciences, University of South Carolina, Columbia

Abstract. Surface geology and seismic and well data from the northwestern flank of the Venezuelan Andes indicate overthrusting of Andean basement rocks toward the adjacent Maracaibo Basin along a blind thrust fault. The frontal monocline is interpreted as the forelimb of a northwestward verging fault-related fold deformed over a crustal-scale ramp. The Andean block has been thrust $20 \mathrm{~km}$ to the northwest and uplifted $10 \mathrm{~km}$ on a ramp that dips about $20^{\circ}-30^{\circ}$ southeastward. The thrust fault ramps up through crystalline basement rocks to a decollement horizon within the shaly units of the Cretaceous Colon-Mito Juan formations. Backthrusts in the monocline produce a wedge geometry and reduce the amount of blind slip required on the decollement northwest of the Andes. The rigid Andean uplift was caused by northwest-southeast compressive tectonic forces related to the convergence of the Caribbean plate, the Panama volcanic arc, and northwestern South America. The thick (up to $6 \mathrm{~km}$ ) molasse deposits accumulated in the foredeep basin indicate that the Venezuelan Andes started to rise as early as the early Miocene. However, a late Miocene intramolasse unconformity marks the beginning of the formation of the monocline and the greatest uplift. The crustal-scale fault-related fold model may explain structural features seen in other areas of basementinvolved foreland deformation.

\section{INTRODUCTION}

Over the past several years, diverse tectonic models have been proposed to explain the Venezuelan Andes uplift. Bucher [1952], Gonzalez de Juana [1952], Hargraves and Shagam [1969], and Shagam [1972] described the Venezuelan Andes as a mega-anticline containing a horst-graben block complex and limited at both flanks by high-angle reverse faults. Rod [1960], Deratmiroff [1971], Schubert [1985], White [1985], Boesi et al. [1988], and Monsalve [1988] proposed that the Venezuelan Andes is a "mushroomlike" transpressional uplift with shear deformation in the Bocono fault system and imbricate thrusting toward both Andean fronts. Hospers and Van Wijnen [1959], Kellogg and Bonini [1982, 1985], Giegengack [1984], and Kohn et al. [1984] noted the asymmetry of the gravity field [Bellizia et al., 1976] and suggested that the Venezuelan Andes uplift was caused by crustal shortening along a southeast dipping "Wind River type" thrust fault.

This paper focuses on the structural interpretation of seismic sections traversing the northwestern flank of the Venezuelan Andes and the southem edge of the Maracaibo Basin between

Copyright 1993 by the American Geophysical Union.

Paper number 93TC01893

0278-7407/93/93TC-01893\$10.00
La Fria and El Vigia (Figures 1 and 2). In this paper we present geological and geophysical evidence for basementinvolved thrusting of the Venezuelan Andes toward the Maracaibo Basin.

\section{GEOLOGIC SETTING}

The regional geologic setting of the area can be described as a mountain front adjacent to a foredeep basin. The mountain front represents a Precambrian-Paleozoic igneous-metamorphic complex partially covered with sediments of Mesozoic and Cenozoic ages. The foredeep is an asymmetric structural basin that contains up to $12 \mathrm{~km}$ of sedimentary section. The early Miocene to Pleistocene molasse deposits up to $6 \mathrm{~km}$ in thickness dominate the sedimentary section. The oldest sedimentary rocks that crop out in the mountain front are Jurassic red beds which are unconformably overlain by a Cretaceous sequence up to $2 \mathrm{~km}$ in thickness. From early Cretaceous to middle Eocene, sediments were deposited in an extensive passive continental margin setting (Figure 3). Coarse clastic sediments of the Rio Negro Formation, bioclastic carbonates of the Apon Formation, and siliciclastic sediments of the Aguardiente Formation were deposited first in the initial stage of the Cretaceous transgressive event. Limestones, calcareous shales, and black shales of the Capacho and La Luna formations represent anoxic facies deposited during the maximum marine transgression of late Cretaceous (Cenomanian-Campanian) age. Regression began in the latest Cretaceous (Maestrichtian) with marine deposition of the shaly Colon Formation and the sandier Mito-Juan Formation. This regression event continued through the Paleocene and middle Eocene with deposition of sandstones, siltstones, shales, and coals of the Orocue Group in a deltaic environment followed by fluvial sandstones of the Mirador Formation. Unconformably overlying this is the upper Eocene paralic facies of the Carbonera Formation which is in turn transitionally covered by lacustrine shales of the Oligocene Leon Formation. Miocene to Recent aged sediments represent continental deposits (Guayabo Group) derived mainly from erosion of the Venezuelan Andes uplift.

The sediments in the mountain front are folded into a steep northwestward dipping monocline. The dip of strata ranges from $25^{\circ}$ to overturned, and the strike is northeast-southwest. Numerous faults, mainly oriented north northwest-south southeast and northeast-southwest, cut and offset the outcropping stratigraphy. The Rio Mocoties fault is considered to be the southwestern continuation of the Bocono right-lateral strike-slip fault.

The gravity field of the area shows a Bouguer anomaly in the north Andean trough of nearly $-150 \mathrm{mGal}$ [Bonini et al., 1977]. This large negative anomaly in the southern edge of the Maracaibo Basin indicates that the basin and the Andes are not in local isostatic equilibrium.

\section{Tectonic Setting}

The intra-Miocene unconformities indicate a major Andean orogeny which has been related to the collision of the Panama island arc with the South American continent [Mann and Burke, 1984; Eva et al., 1989]. The resulting collision and the oblique subduction of the Carnegie ridge beneath the Andes in Ecuador may have caused the uplift of the Eastern Cordillera of Colombia and the detachment of the North Andes block or microplate along the Bocono and the East Andean frontal fault 


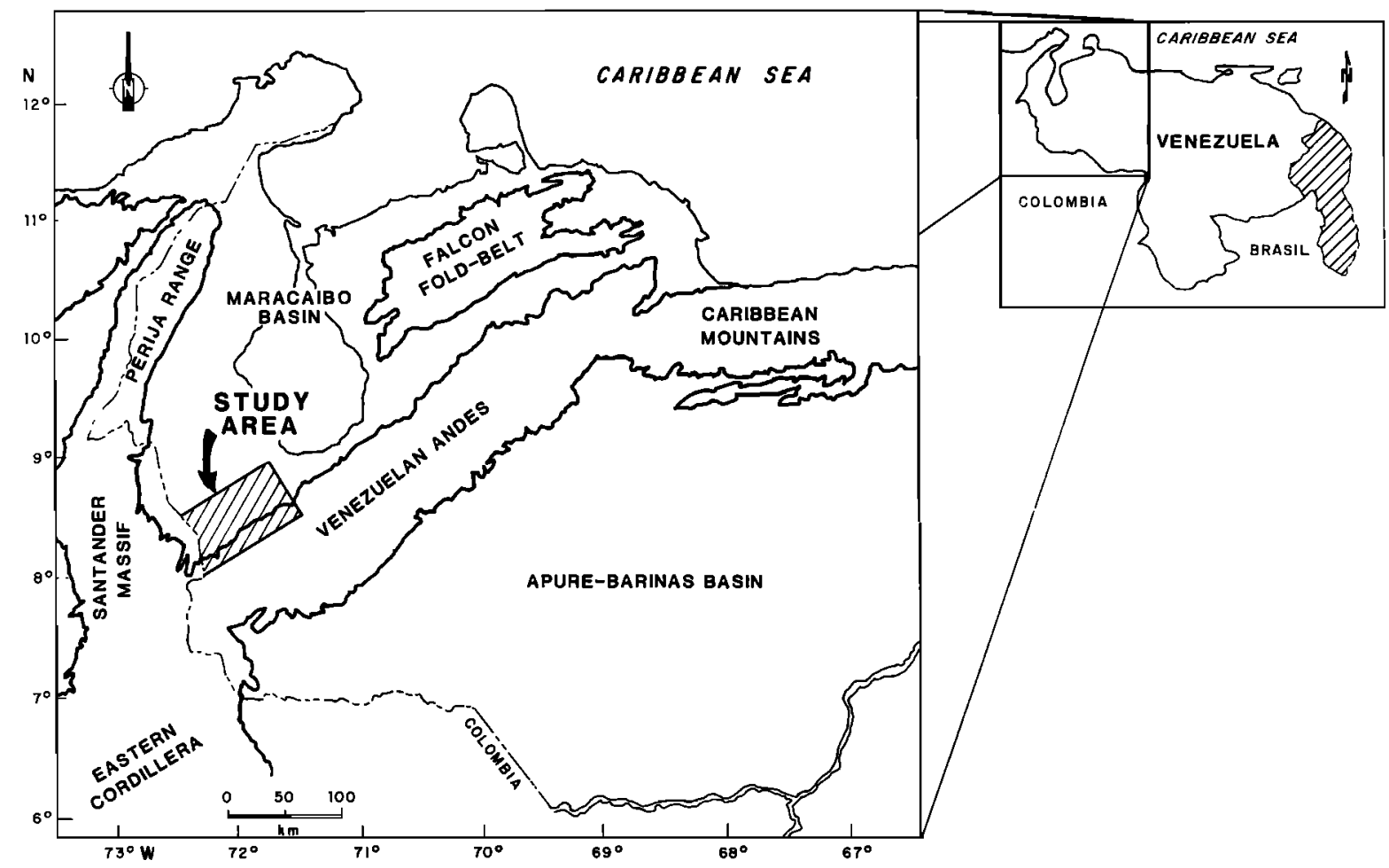

Fig. 1. Location map of the study area.

system [Pennington, 1981; Kellogg et a1., 1985]. The limited cumulative displacement on the Bocono fault [Stephan, 1977; Gonzalez de Juana et al., 1980; Schubert, 1982; Giegengack, 1984], despite the relatively rapid present-day slip rate of 1 $\mathrm{cm} / \mathrm{yr}$ [Schubert, 1980; Aggarwal, 1983], suggests that most of the northeastward movement of the North Andes block occurred in the last 5 or 10 m.y. [Kellogg, 1984; Macellari, 1984].

Global plate motion models predict west northwest-east southeast convergence for the Caribbean and South American plates [Jordan, 1975; Minster and Jordan, 1978; DeMets et al., 1990]. The north-south vector component is even greater for Caribbean-North Andean convergence when the North Andean movement northeastward relative to South America on the Bocono fault system is added. The direction of maximum shortening in the Venezuelan Andes is northwest-southeast. Kellogg and Bonini [1982, 1985] and Kellogg [1984] suggested that this vector of deformation is related to slow convergence $(1.7 \pm 0.7 \mathrm{~cm} / \mathrm{yr})$ between the Caribbean plate and the North Andean microplate at the South Caribbean marginal fault (Figure 4). This compressive deformation was also responsible for the uplifts of the Sierra de Perija and the Sierra Nevada de Santa Marta. Present-day amagmatic subduction along the South Caribbean marginal fault is indicated by active folding and thrusting in the South Caribbean deformed belt [Lehner et al., 1983; Ladd et al., 1984] and by a southeast dipping Wadati-Benioff zone [Dewey, 1972; Pennington, 1981; Kellogg and Bonini, 1982; Toto and Kellogg, 1992]. Pennington [1981] and Daniels [1991] estimated the dip of the Wadati-Benioff zone as $20^{\circ}$. Preliminary results from Central and South America (CASA) Global Positioning System (GPS) satellite geodetic measurements over a 3-year period
(1988-1991) show of the order of 1 to $2 \mathrm{~cm} / \mathrm{yr}$ convergence between the Caribbean, Panama, and North Andean plates [Vega et al., 1991]. "Thick-skinned" basement-involved deformation has been correlated with magmatic gaps and lowangle or flat subduction in the Pampeanas Range of Argentina [Jordan et al., 1983; Jordan and Allmendinger, 1986] and the North American Cordillera [Lipman et al., 1971; Burchfiel and Davis, 1975; Coney, 1976; Dickinson and Snyder, 1978].

\section{Comparisons to Other Basement-Involved Foreland Deformations}

Structural features in the Venezuelan Andes are similar to those associated with the Laramide orogeny (40-70 m.y.) in the central and southern Rocky Mountains of the United States. The basement block tectonic style of the Laramide orogeny is characterized by the movement of basement blocks along reverse faults. The overlying sediments in many areas fold over reverse faulted basement blocks forming the monoclines [Stearns, 1971; Stearns and Weinberg, 1975; Matthews, 1978; Narr, 1993; Narr and Suppe, submitted manuscript] analogous to the bruchfalten (fault folds) of Stille [1925]. Local secondary normal faults occur [Wise, 1963; Howard, 1966; Steams, 1971], but gravity data and Consortium for Continental Reflection Profiling (COCORP) deep seismic reflection profiling show that regional shortening far exceeds extension [Berg, 1962; Berg and Romberg, 1966; Smithson et al., 1978]. The structural relief on the basement surfaces exceeds $12 \mathrm{~km}$ for the Wind River and Sweetwater uplifts [Prucha et al., 1965].

Other active Andean mountain belts that are structurally analogous to the basement-involved Laramide orogeny in the 


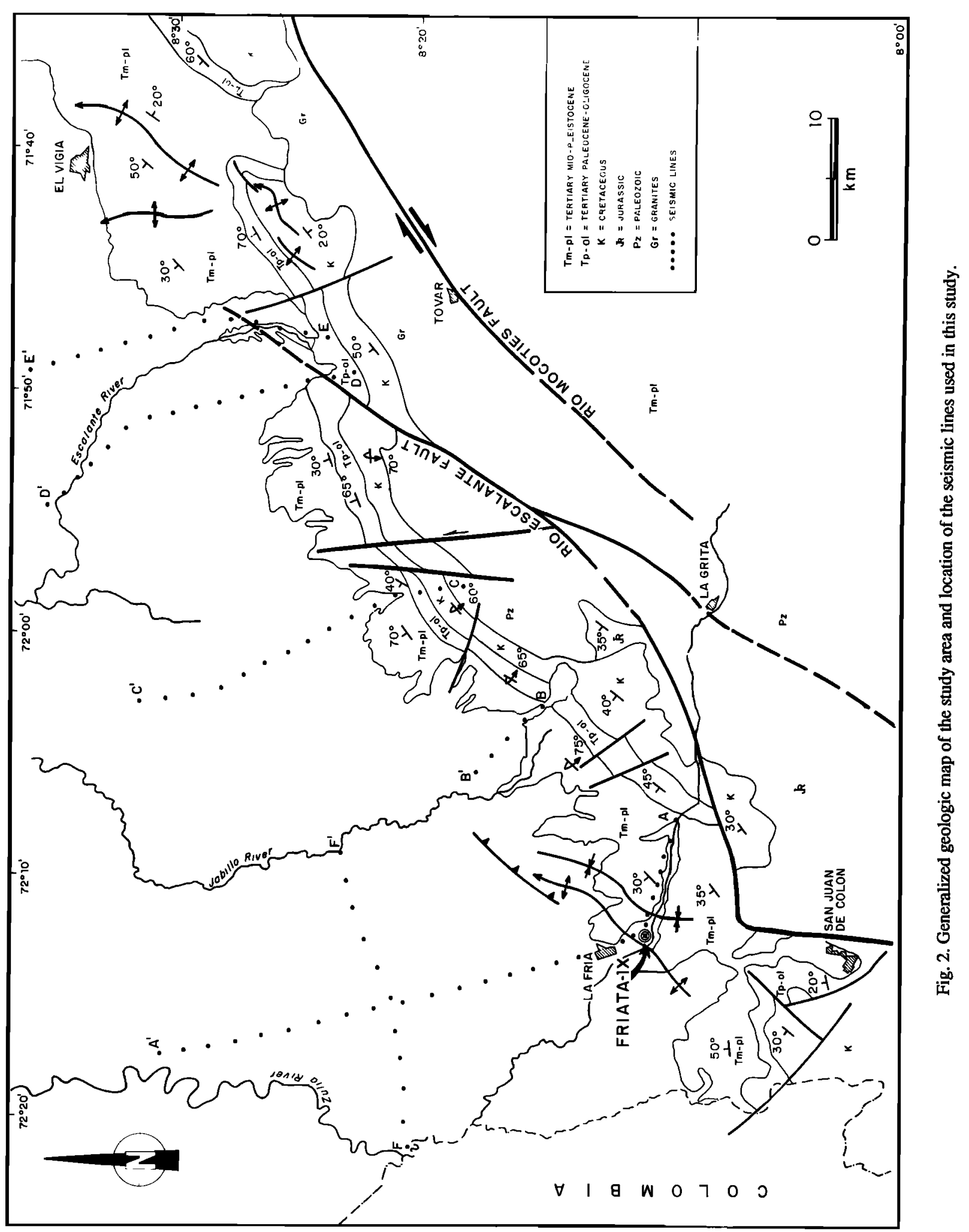




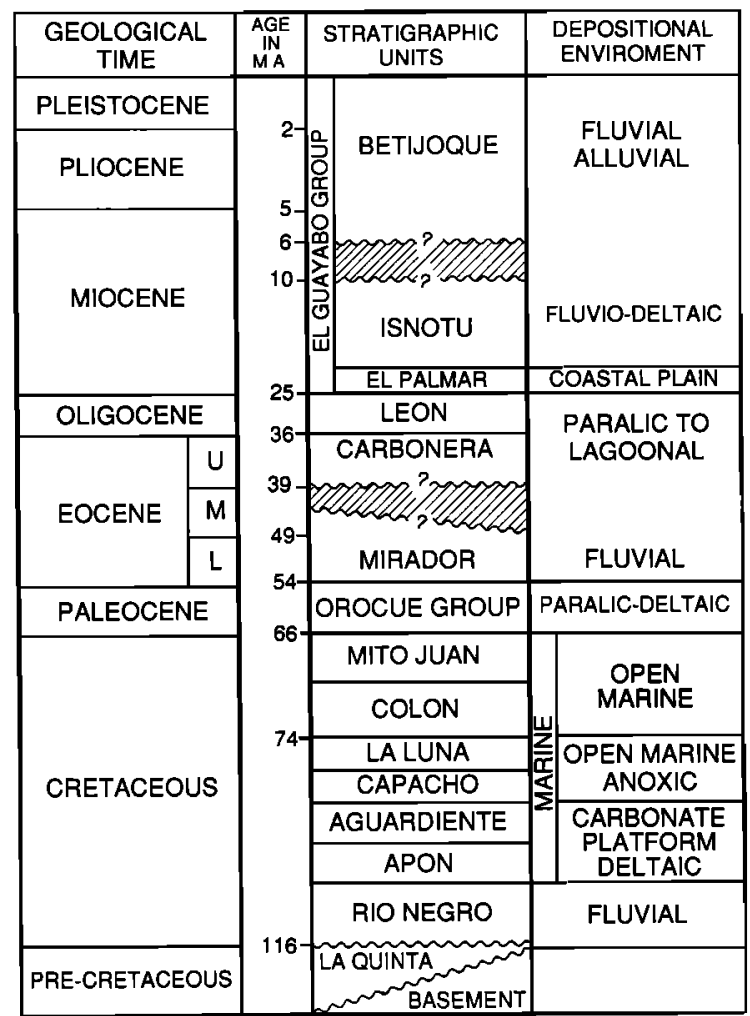

Fig. 3. Stratigraphy of the north Andean flank.

middle and southern Rocky Mountains include the Sierra de Perija on the Colombian-Venezuelan border and the Sierra Nevada de Santa Marta of Colombia [Kellogg and Bonini, 1982], the Peruvian Andes [Audebaud et al., 1973], and the Sierras Pampeanas of Argentina [Jordan et al., 1983; Jordan and Allmendinger, 1986]. A similar style has been recognized in middle and northern Germany [Stille, 1910; Lotze, 1938], the Arbuckle-Wichita Mountains [Fichter, 1954], the Permian basin of west Texas [Elam, 1969], and the Laramide fault block uplifts and related monoclines of the Colorado Plateau [Kelly, 1955].

\section{DATA AND METHOD}

The data used in this study include seismic sections, surface geology, and the Friata-1X well log [DeToni, 1990]. Five seismic lines traversing the Andean mountain front between La Fria and E1 Vigia (Figure 2) were selected for this study.

To interpret the seismic profiles, the time sections were converted to depth sections: the travel times of prominent seismic horizons were converted to approximate depths in meters, using stacking velocities. Wherever possible, these seismic horizons were correlated with the exposed surface stratigraphy. The geologic solutions presented in this paper are qualitative descriptions and do not presume to describe the structure quantitatively (i.e., the cross sections are not balanced/retrodeformable).

\section{SEISMIC INTERPRETATION}

In seismic profiles of the area, two seismic provinces are recognized: the Andean frontal monocline and the foredeep basin. The southern portion which corresponds to the frontal monocline is characterized by discontinuous seismic horizons dipping to the northwest. The major seismic reflectors can be correlated with geologic units exposed at the surface. The northern portions of the seismic sections correspond to the foredeep basin. This zone shows well-defined, continuous seismic reflectors dipping gently to the southeast. The deeper reflectors are discontinuous at the mountain front and cannot be correlated with the reflectors present in the frontal

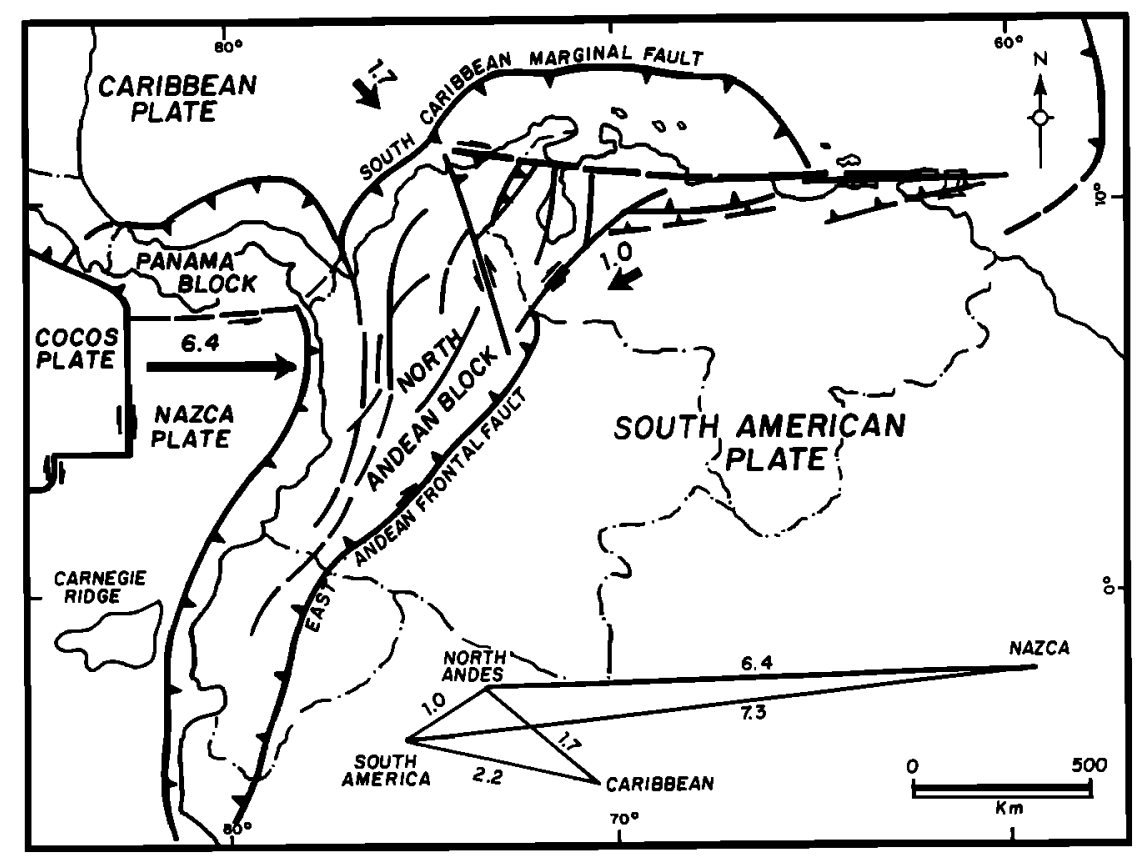

Fig. 4. Present-day plate motions (solid arrows) relative to the north Andean block showing average slip rates (in centimeters per year) during the last 5-10 m.y. [after Kellogg and Bonini, 1985]. 
monocline. As a result of this lack of lateral correlation, some Cretaceous units in the foredeep basin were identified by correlation of acoustic character with an interpreted seismic line and a synthetic trace for a well in the Los Manueles oil field (Figure 5).

\section{Frontal Monocline}

Mesozoic and Cenozoic rocks are exposed in the Andean frontal monocline in a narrow belt that follows the regional northeast-southwest trend. Here the Cretaceous rocks were uplifted up to $10 \mathrm{~km}$ above the same units in the flanking foredeep basin. The exposed Cretaceous and Tertiary beds show moderate to steep northwestward dips. These dips are consistent over much of the study area. To the southeast the dip of the monocline steepens, and in some places the beds are overturned. The seismic data constrain the structural interpretation at depth.

Based on the seismic and surface geology information, the frontal monocline has been interpreted as the hanging wall forelimb of a major fault bend fold structure [Suppe, 1983]. A blind thrust fault is located in a bedding plane decollement beneath the mountain front monocline. Reflectors correlated to the La Luna Formation and older rocks are involved in the hanging wall cutoffs. The thrust fault slips basinward into a bedding plane decollement in the Upper Cretaceous ColonMito Juan shales (Figures 8, 10, 12, 14, and 16). This interpretation requires the presence of a regional southeast dipping ramp south of the sections. The structural configuration of the frontal monocline is complicated by northwest dipping backthrusts and southwest dipping highangle reverse faults.

In the section A-A' (Figures 6, 7, and 8), Upper Cretaceous and Tertiary units are folded in the La Friata anticline by a series of backthrusts. One backthrust fault is predicted in a bedding plane decollement in the Colon-Mito Juan formations stepping up into a higher detachment at the base of the Paleocene. Although prediction of this fault explains at least $2 \mathrm{~km}$ of shortening in the Lower Tertiary units, the major shortening in the anticline occurs within the Oligocene units. The Friata-1X well log shows an unusually thick sequence $(1658 \mathrm{~m}$ ) of Oligocene Leon Formation shales (Figures 7 and 8). The thick shale sequence is interpreted as a duplex consisting of five overlapping ramp anticlines. The solution shown in Figure 8 requires approximately $17 \mathrm{~km}$ of slip at the Oligocene/Eocene contact. If, however, the original thickness of the Oligocene Leon Formation in the line of the section was $500-800 \mathrm{~m}$, only one or two overlapping ramp anticlines
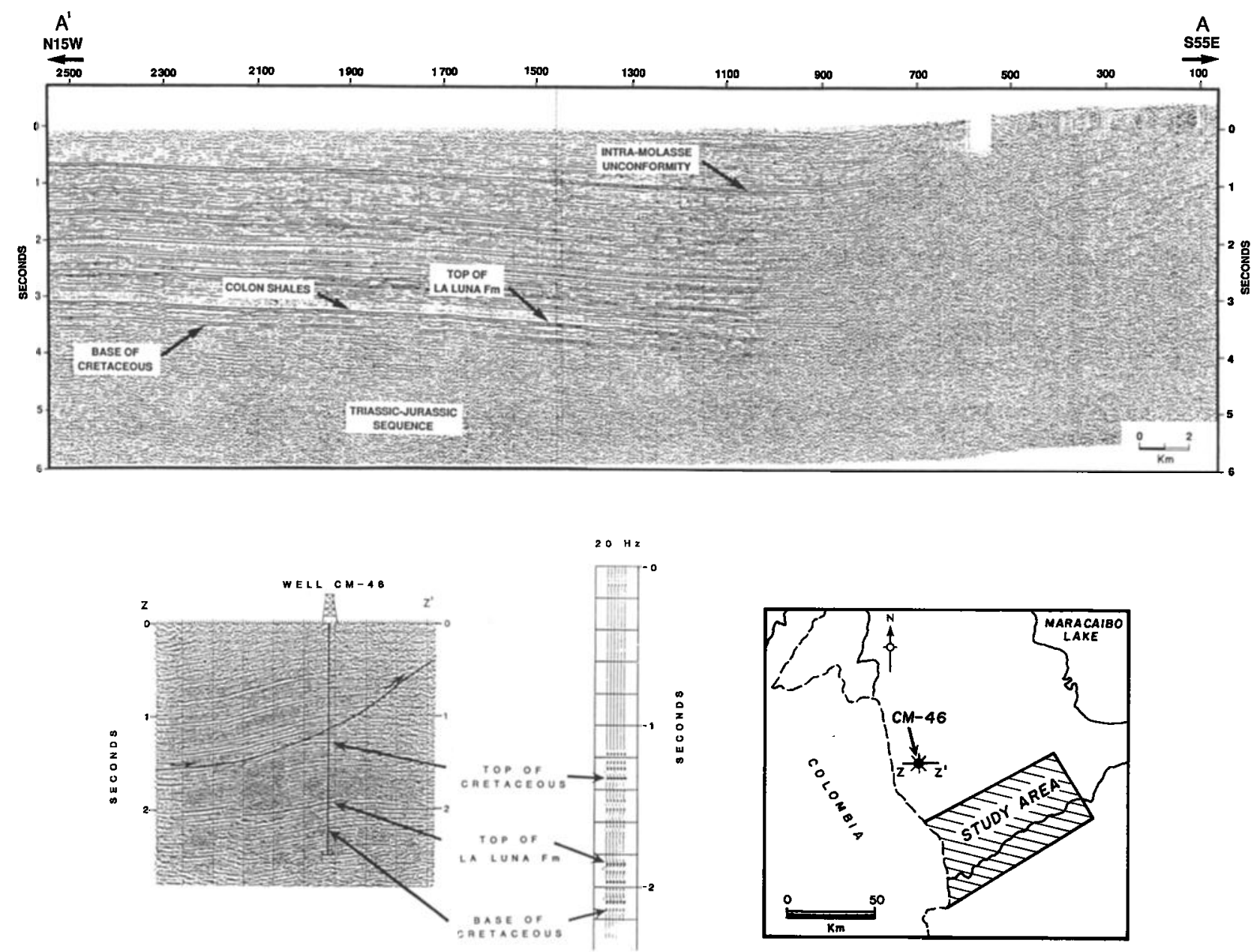

Fig. 5. Identification of the stratigraphic units in the foredeep basin (section A-A' in Figure 2) based on interpreted seismic line Z-Z' and synthetic trace of well CM-46 in the Los Manueles oil field. 


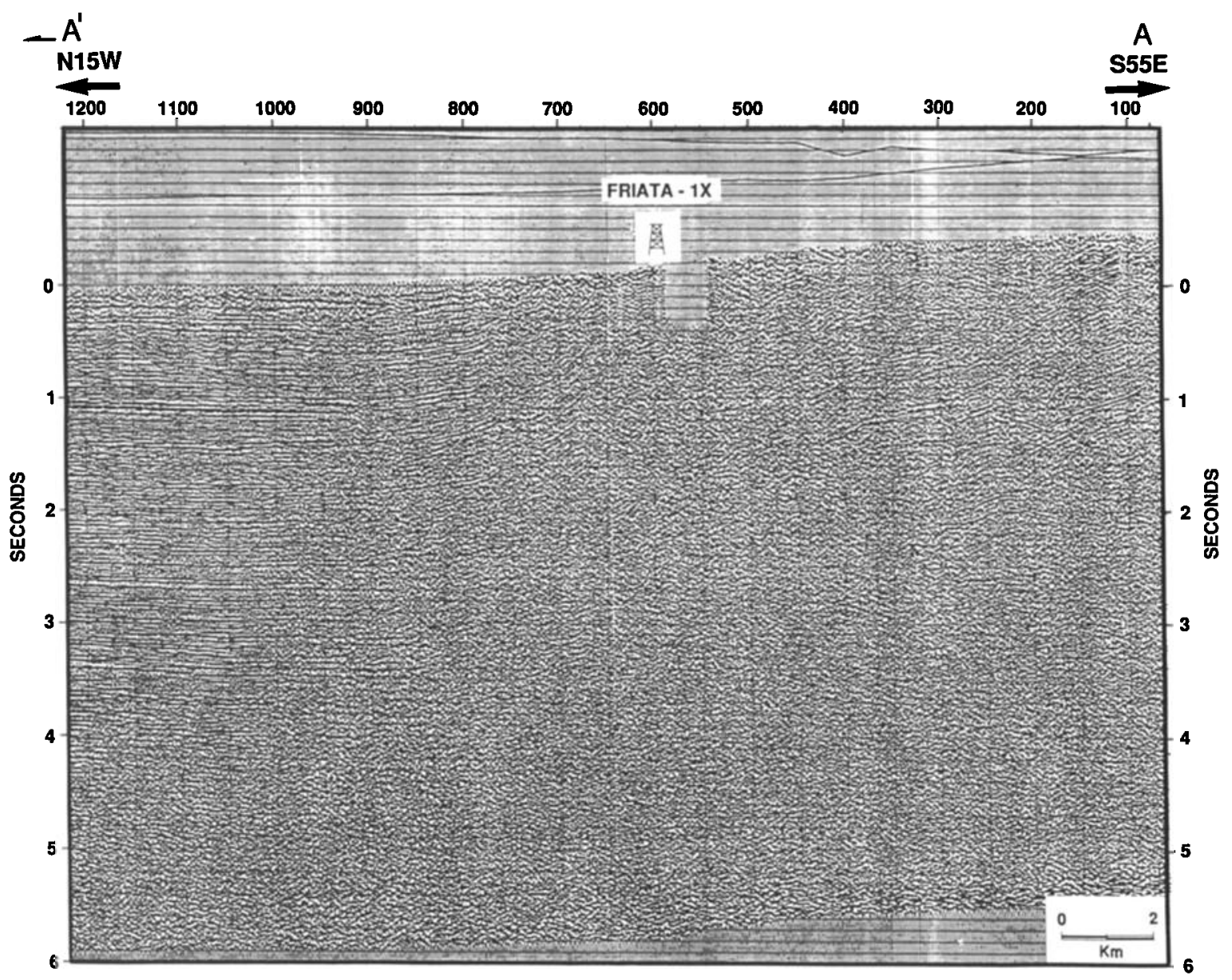

Fig. 6. Seismic section A-A' showing the location of the Friata-1X well.

and 4-8 km of slip would be required. Structural solutions with one or two ramps are compatible with the dip log data from the Friata-1X well (Figure 7), which suggests two or three distinct dip domains.

In seismic section B-B' (Figure 9), subhorizontal reflectors at 4.1-4.4 $\mathrm{s}$ underlie steeply dipping reflectors in the monocline. The subhorizontal reflectors are interpreted as undeformed Cretaceous units in the footwall (Figure 10) beneath a bedding plane decollement in the Upper Cretaceous Colon-Mito Juan shales.

Structural discontinuity of seismic reflections in the upper part of the profile C-C' (Figure 11) was related to a backthrust fault within the Miocene units (Figure 12). The Rio Escalante fault in section D-D' (Figures 13 and 14) and E-E' (Figures 15 and 16 ) is also a backthrust with $1-3 \mathrm{~km}$ of displacement. The Rio Escalante fault trace is oblique to the mountain front (Figure 2). In section D-D' this backthrust appears to step up from a decollement at the top of the Paleocene, whereas in section E-E' the fault is steeper and probably rooted in a bedding plane in Cretaceous units. Two more minor backthrusts are shown in Figure 16: one in the upper molasse sequence at the front of the monocline and another in the Cretaceous south of the Rio Escalante fault

Two imbricated fault-related folds steepen the frontal monocline in section D-D' (Figures 13 and 14). Steepening of middle Miocene strata indicates post middle Miocene formation of this duplex structure. Shallow onlapping reflections in the upper part of the profiles (Figures 13 and 15) suggest a period of Plio-Pleistocene erosion and monocline growth.

The fault bend fold interpretation for the Andean front would explain the $12 \mathrm{~km}$ of vertical uplift of the pre-Cretaceous units traversed by the sections. A minimum lateral shortening of 20 $\mathrm{km}$ is estimated for the interpreted structures.

\section{Foredeep Basin}

The foredeep basin is the structural depression of the southern Maracaibo Basin that is adjacent and parallel to the Venezuelan Andes. The basin is an asymmetric trough that contains up to $12 \mathrm{~km}$ of Cretaceous and Tertiary sediments. This sedimentary section is dominated by more than $6 \mathrm{~km}$ of Miocene to Recent molasse deposits derived from the erosion of the rising Andes. A major regional unconformity separates this thick clastic wedge into two different molasse units (Figures 5,6, and 17). Structural deformation of the foredeep basin is mainly restricted to the mountain front; however, some minor normal faults offset seismic horizons correlated with the Cretaceous units (Figures 6,8, and 15). The displacement of the faults is apparently absorbed or truncated in the reflection free zone produced by the Cretaceous ColonMito Juan formation shales.

We attribute the structural configuration of the foredeep and 


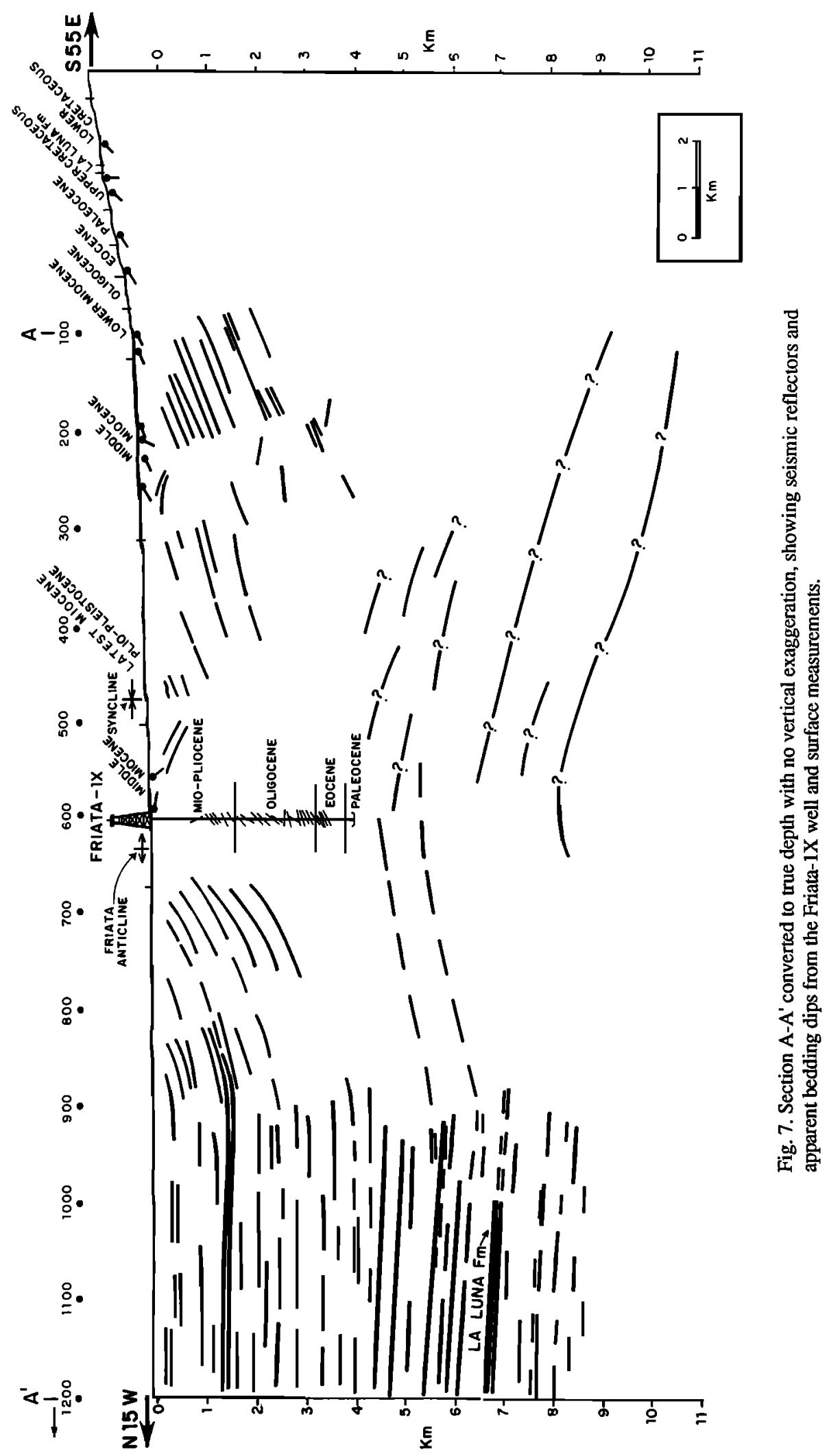




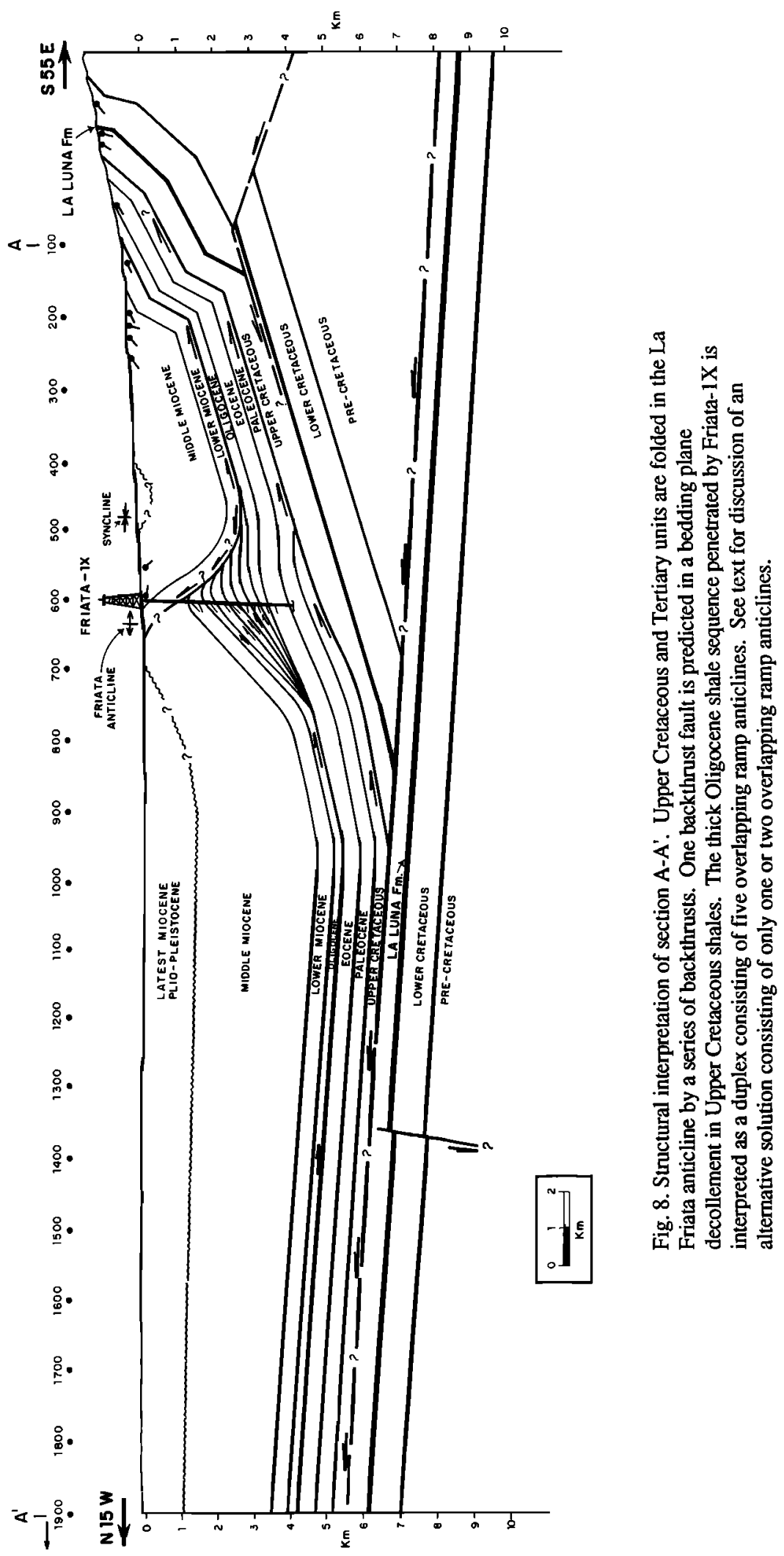


$B^{\prime}$

B

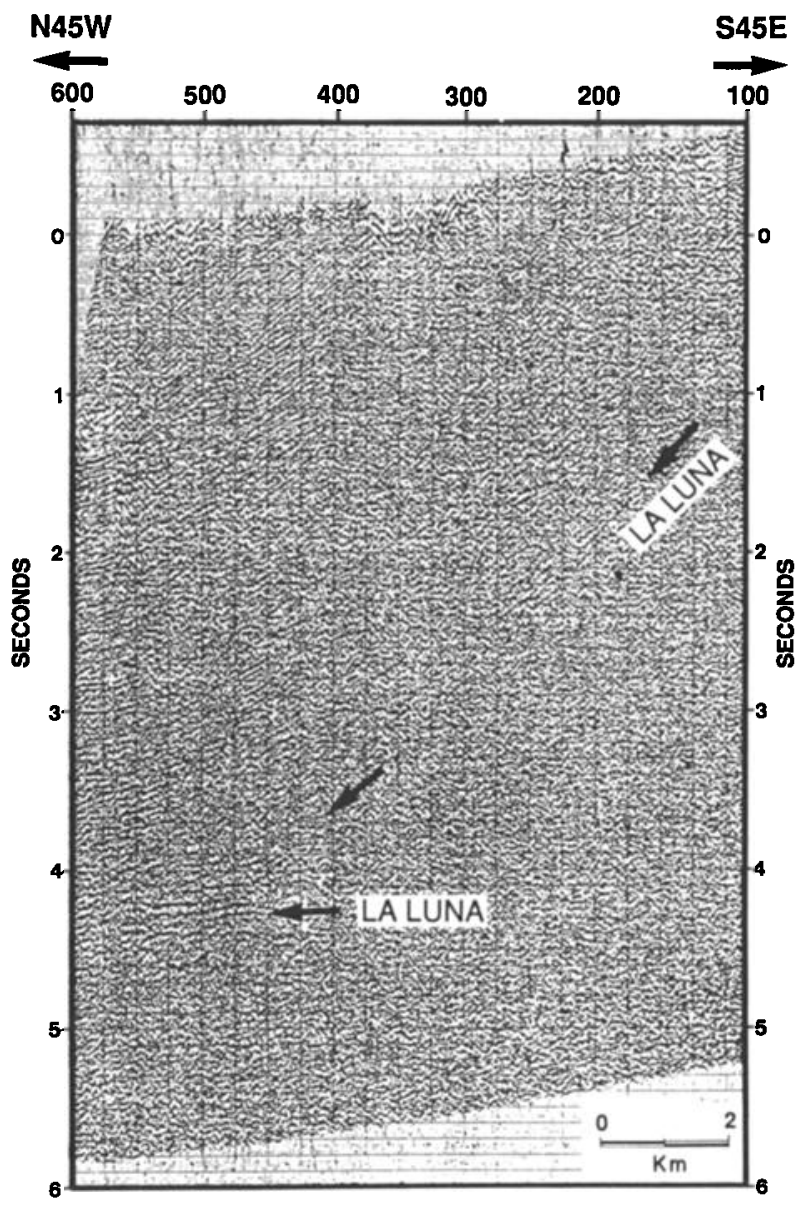

Fig. 9. Seismic section B-B'. Beneath the steeply dipping reflectors in the monocline note the subhorizontal reflectors at 4.1-4.4 s. Dashed lines indicate the location of reflectors interpreted as being associated with the La Luna Formation.

the regional southeastward tilting of the seismic reflectors to flexure of the lithosphere as a response to tectonic loading by the Venezuelan Andes. The normal faults at the base of the sedimentary section in the foredeep basin may be secondary features produced by the bending stresses.

\section{DISCUSSION}

\section{Crustal Scale Fault-Related Folding and Wedge Structure}

The seismic sections presented in this paper show considerable shortening by imbricate backthrust and breakthrough faults within the monocline on the northwestern front of the Venezuelan Andes. Sediments monoclinally draped over a vertical or normal basement fault would be extended by normal faulting or ductile thinning [Brown, 1988] which is not observed. The reverse faulting observed in the sediments therefore indicates reverse faulting and shortening in the basement. We have therefore interpreted the Venezuelan Andes as a northwestward verging fault bend fold structure deforming over a crustal-scale ramp (Figures 18a and 18b). Estimates of the fault dip range from $20^{\circ}-25^{\circ}$ based on gravity models [Kellogg and Bonini, 1982, 1985] to about $27^{\circ}$ from fault bend fold theory for a $38^{\circ}$ frontal limb dip [Suppe, 1983]. The simplified solution shown in Figure $18 \mathrm{~b}$ shows a lowangle $\left(20^{\circ}\right)$ ramp, (1) from fault bend fold theory for the $20^{\circ}$ $23^{\circ}$ frontal limb dips in profiles A, C, and D (Figures 8, 12, and 14) and (2) so that the monocline on the southeastern flank of the Venezuelan Andes could be explained as the backlimb of the same fault bend fold that formed the northwestern flank . The low-angle ramp lies within the range of solutions compatible with the gravity data [Kellogg and Bonini, 1982, 1985]. The high dip angles shown in profiles B, C, D, and E (Figures 10, 12, 14, and 16) are interpreted as frontal limb dips produced by imbricate thrust faults not shown in Figure $18 \mathrm{~b}$. The Andes are thrust $20-30 \mathrm{~km}$ northwestward toward the Maracaibo Basin. Vertical relief on the top of basement is more than $12 \mathrm{~km}$. The fault ramps up to a decollement horizon within the Cretaceous Colon-Mito Juan formation shales. The northwestward movement of the Andean basement folded the hanging wall sedimentary sequence and produced the steep monocline of the north Andean flank. Deep subhorizontal reflectors beneath the monocline are interpreted as undeformed Cretaceous units in the footwall (Figures 9 and 10). Backthrusts in the monocline produce a wedge geometry [Tearpock and Bischke, 1991] and reduce the amount of blind slip required on the decollement northwest of the Venezuelan Andes.

Our interpretation is supported by new seismic lines [Audemard, 1991] that show a major decollement in the Upper Cretaceous Colon shales and backthrusting within Colon, Lower Tertiary, and Molasse units. Backthrusts consist of fault bend folds, fault propagation folds, and duplexes. Northwest verging duplexes involve the basement.

Nonscaled rock models of low-angle reverse faults deformed under confining pressure show late stage basement structures developed through fracture, imbricate faulting, and rotation of basement blocks between zones of cataclasis [Chester et al., 1988]. Overlying the uplifted basement block in the models is a continuous, flat-topped, asymmetric kink fold in the veneer having one near-vertical limb. The steeply dipping limb is analogous to the monocline on the northwestern flank of the Venezuelan Andes.

\section{Timing of Deformation}

The thick molasse deposits accumulated in the foredeep basin provide the most direct evidence for timing the Andean thrusting and uplift. These sediments, represented by the El Guayabo Group (El Palmar, Isnotu, and Betijoque formations), suggest that the Venezuelan Andes started to rise as early as the early Miocene, with the formation of the monocline and the greatest uplift in late Miocene to Pleistocene times.

The El Guayabo Group has always been described as one uninterrupted cycle of continental sedimentation [Gonzalez de Juana et al., 1980]. However, the seismic data show an important intramolasse unconformity, indicating that two different sedimentation cycles are separated by a period of tectonic interruption. This unconformity is most pronounced in the western portion of the study area (Figure 17). In outcrops of the north Andean mountain front, the intramolasse discontinuity is not readily observed; however, in the southwestern flank (Tachira Depression) the unconformity can 


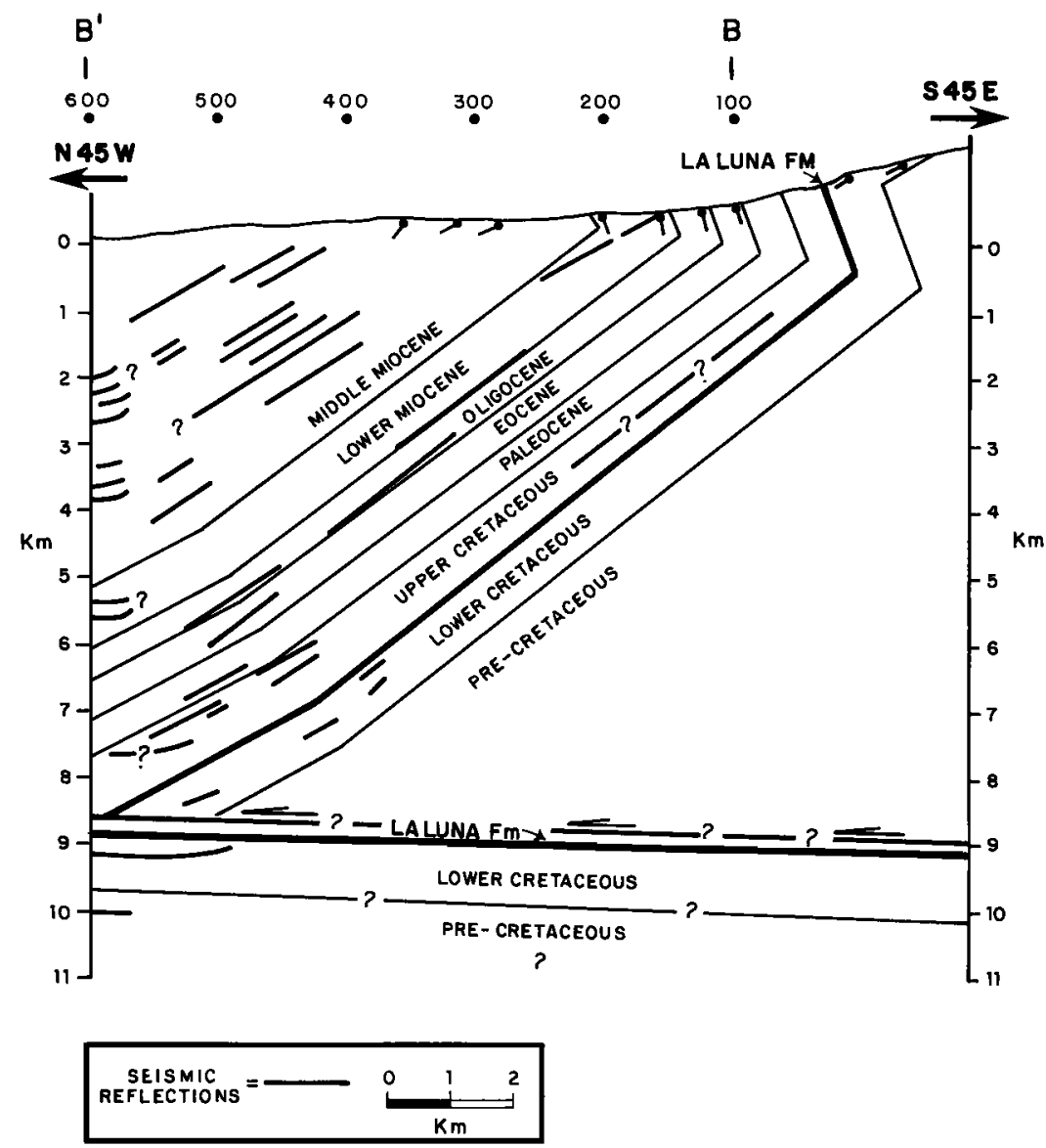

Fig. 10. Structural interpretation of seismic section B-B' with no vertical exaggeration, showing seismic reflectors and apparent bedding dips at the surface. The subhorizontal reflectors are interpreted as undeformed Cretaceous units in the footwall beneath a bedding plane decollement in the Upper Cretaceous shales.

C'

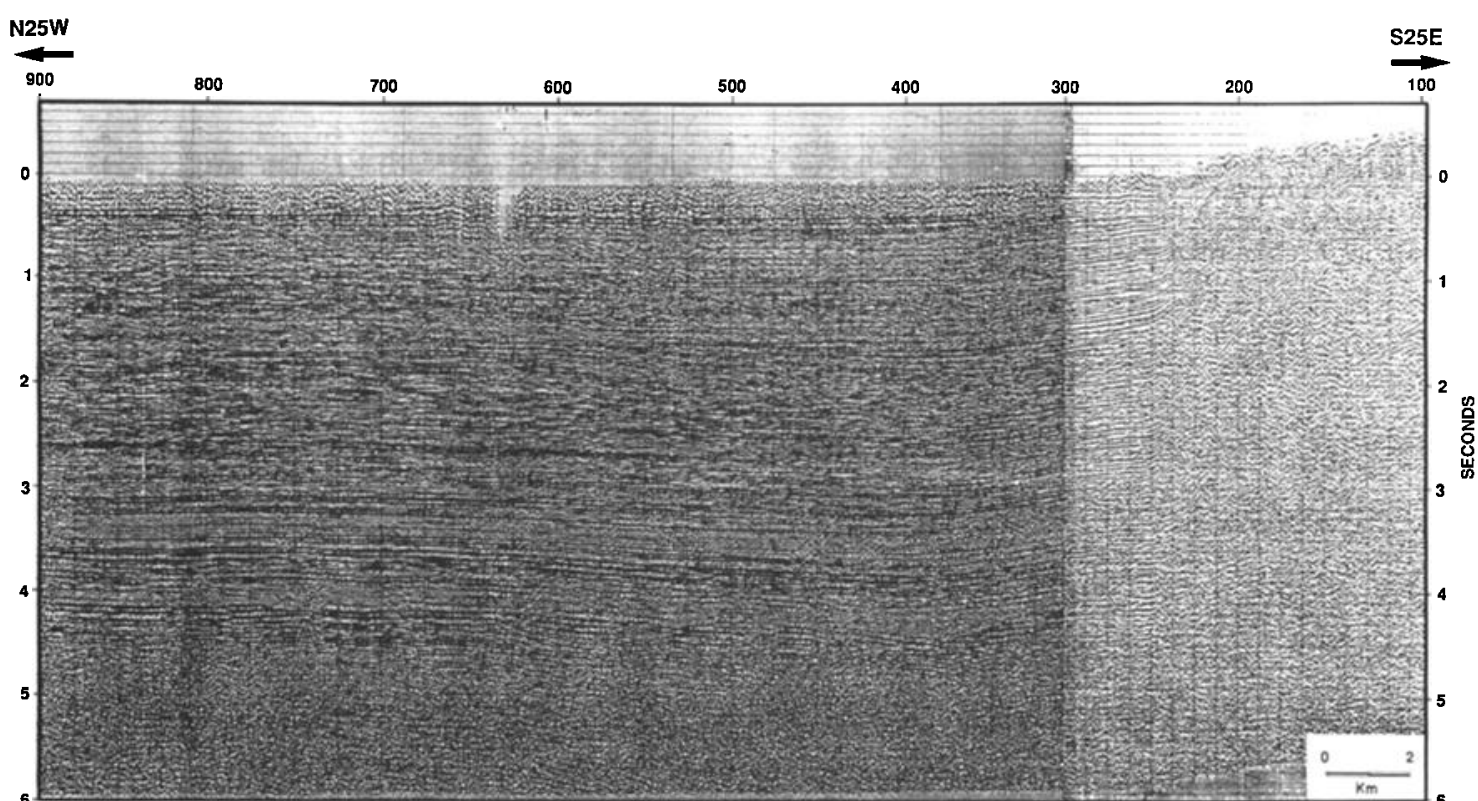

Fig. 11. Seismic section C-C'. 


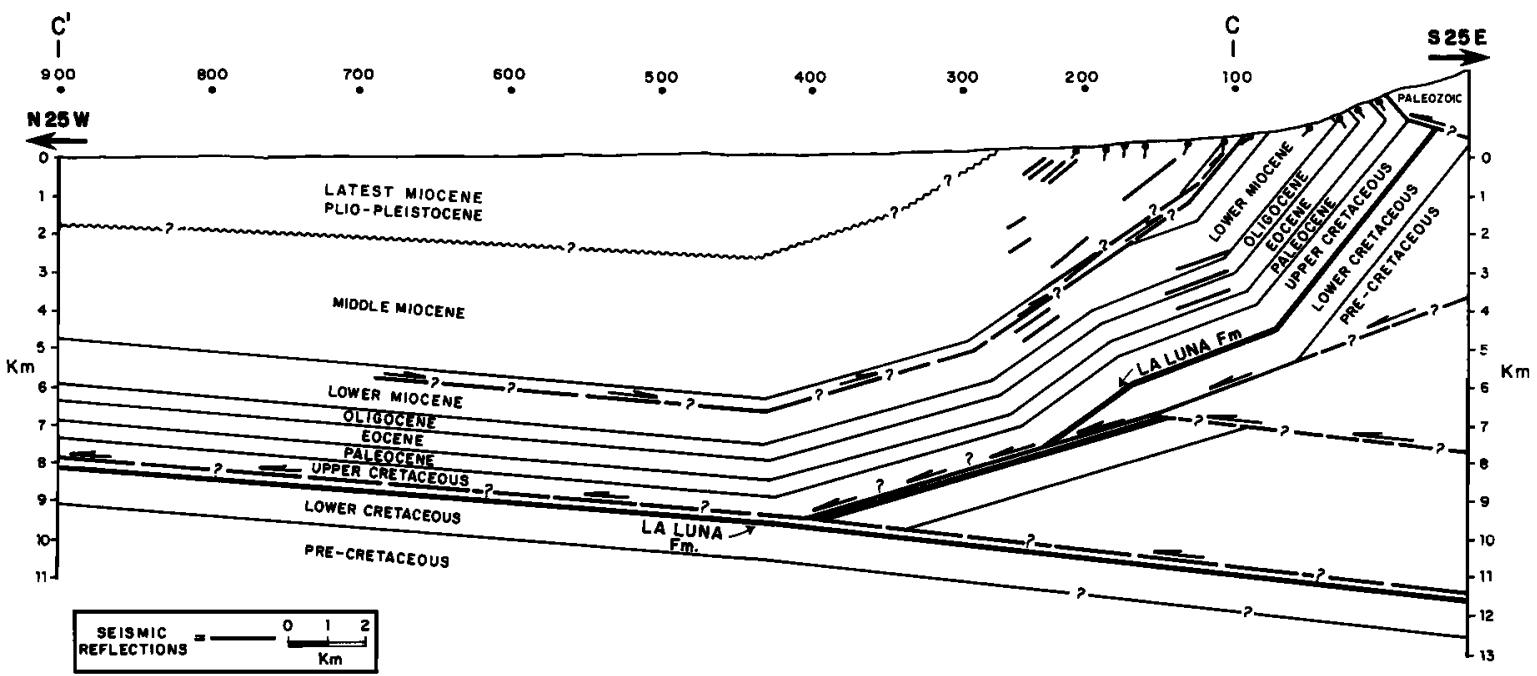

Fig. 12. Structural interpretation of section C-C" showing seismic reflectors and apparent bedding dips from surface measurements.

be distinguished and occurs beneath the fluvial latest Miocene sediments of the La Cope Formation [Macellari, 1984]. This intra-Miocene event has also been found in seismic sections of the Barinas-Apure Basin and in most of the intermontane basins of northwestern Colombia [Meier et al., 1987; Chigne, 1985; Eva et al., 1989].

\section{SUMMARY}

The seismic reflection profiles of the northwestern flank of the Venezuelan Andes presented in this paper are consistent with our interpretation of the range as a fault-related fold structure deformed over a crustal-scale ramp. The ramp dips about $20^{\circ}-30^{\circ}$ southeast, and the Andean basement was thrust 20-30 km northwestward toward the Maracaibo Basin. The blind thrust fault steps into a bedding plane decollement horizon within the Cretaceous Colon-Mito Juan formation shales. The northwestward movement of the Andean basement folded the hanging wall sedimentary sequence and produced a steep monocline. Backthrusts in the monocline produce a

D'

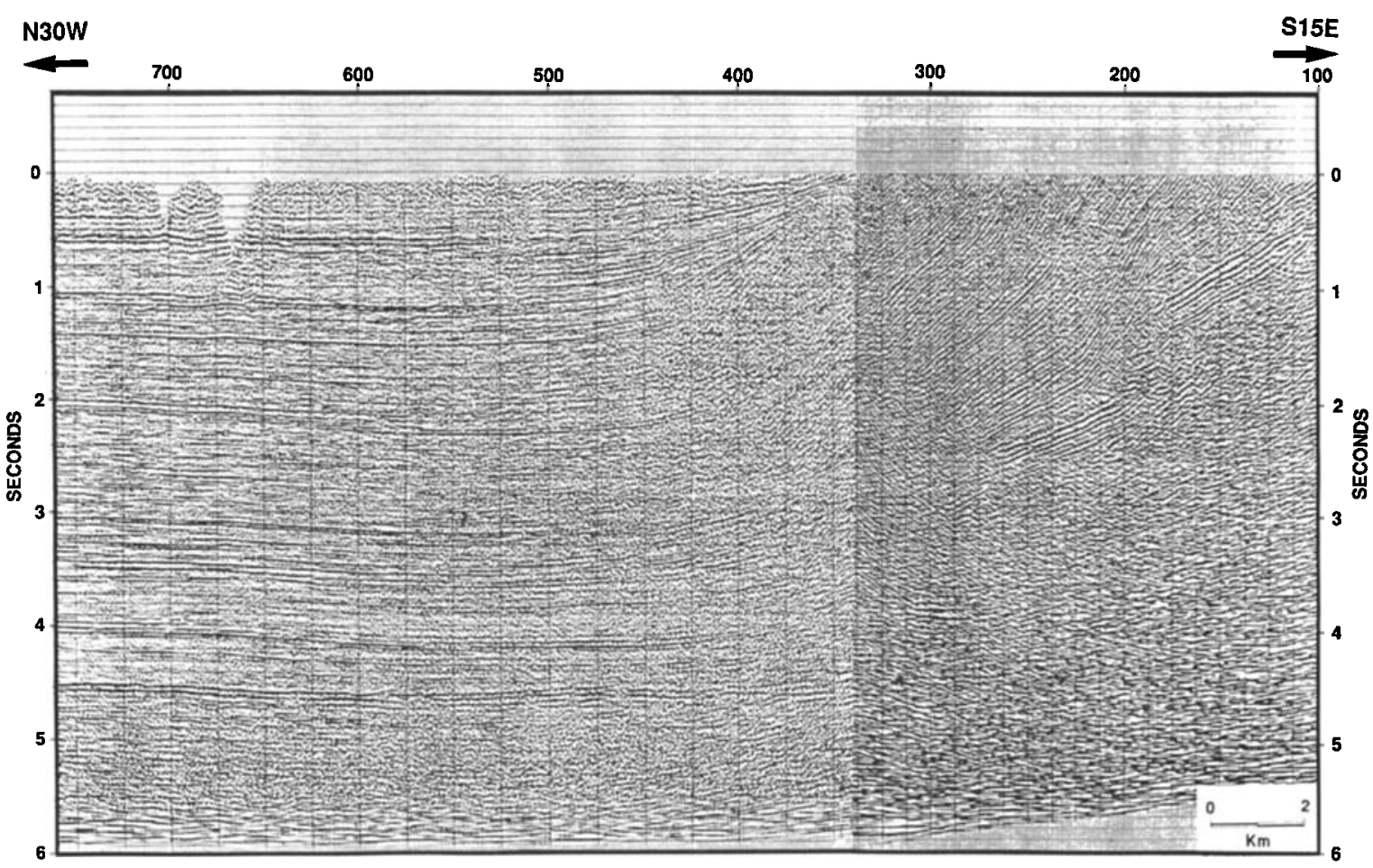

Fig. 13. Seismic section D-D'. 


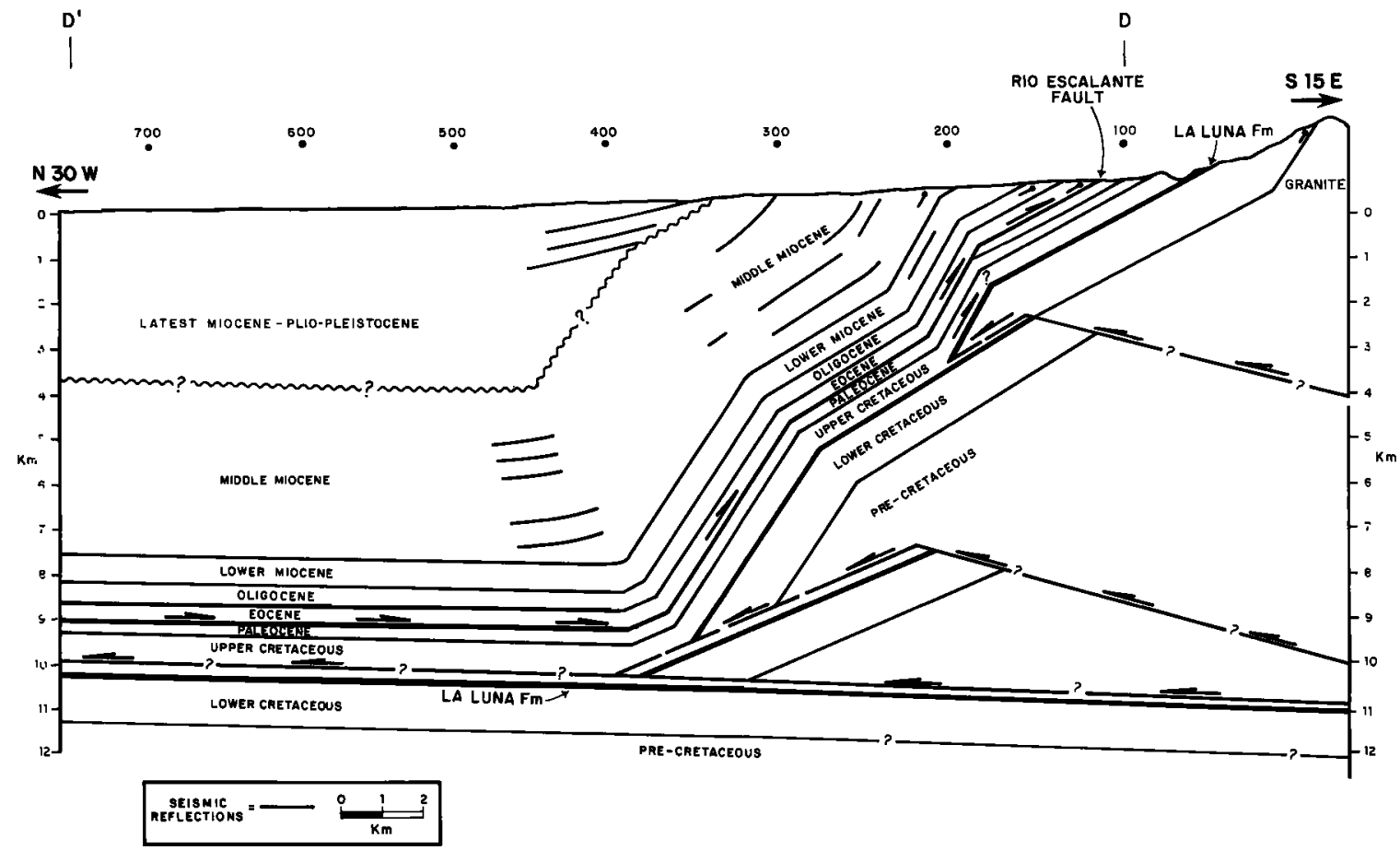

Fig. 14. Structural interpretation of seismic section D-D' showing seismic reflectors and apparent bedding dips. Imbricate southeast dipping thrusts within the basement and northwest dipping backthrusts within the sedimentary cover steepen the monocline. Discordant reflectors between SP350 and SP450 suggest a late Miocene unconformity associated with the formation of the monocline.

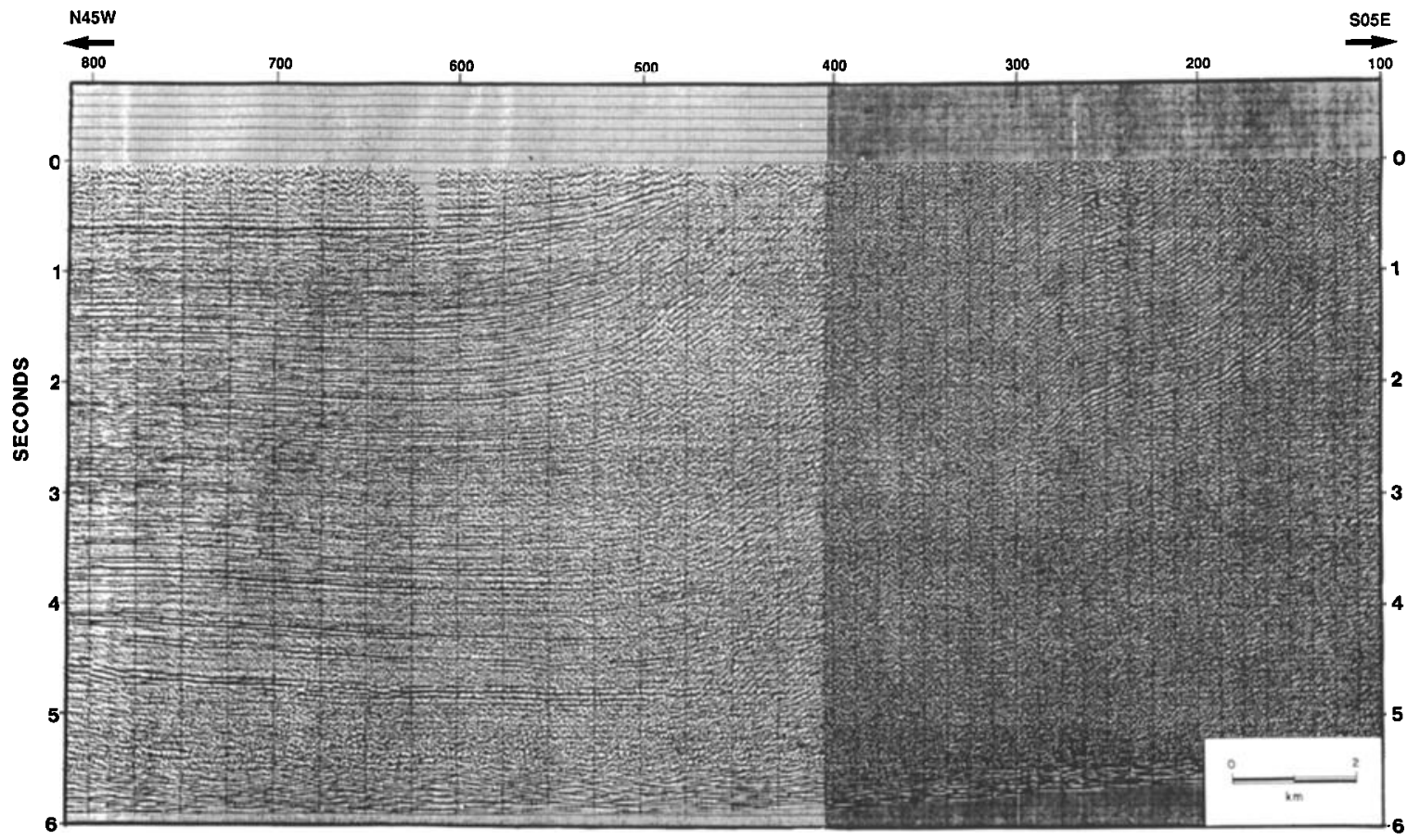

Fig. 15. Seismic section E-E'. 


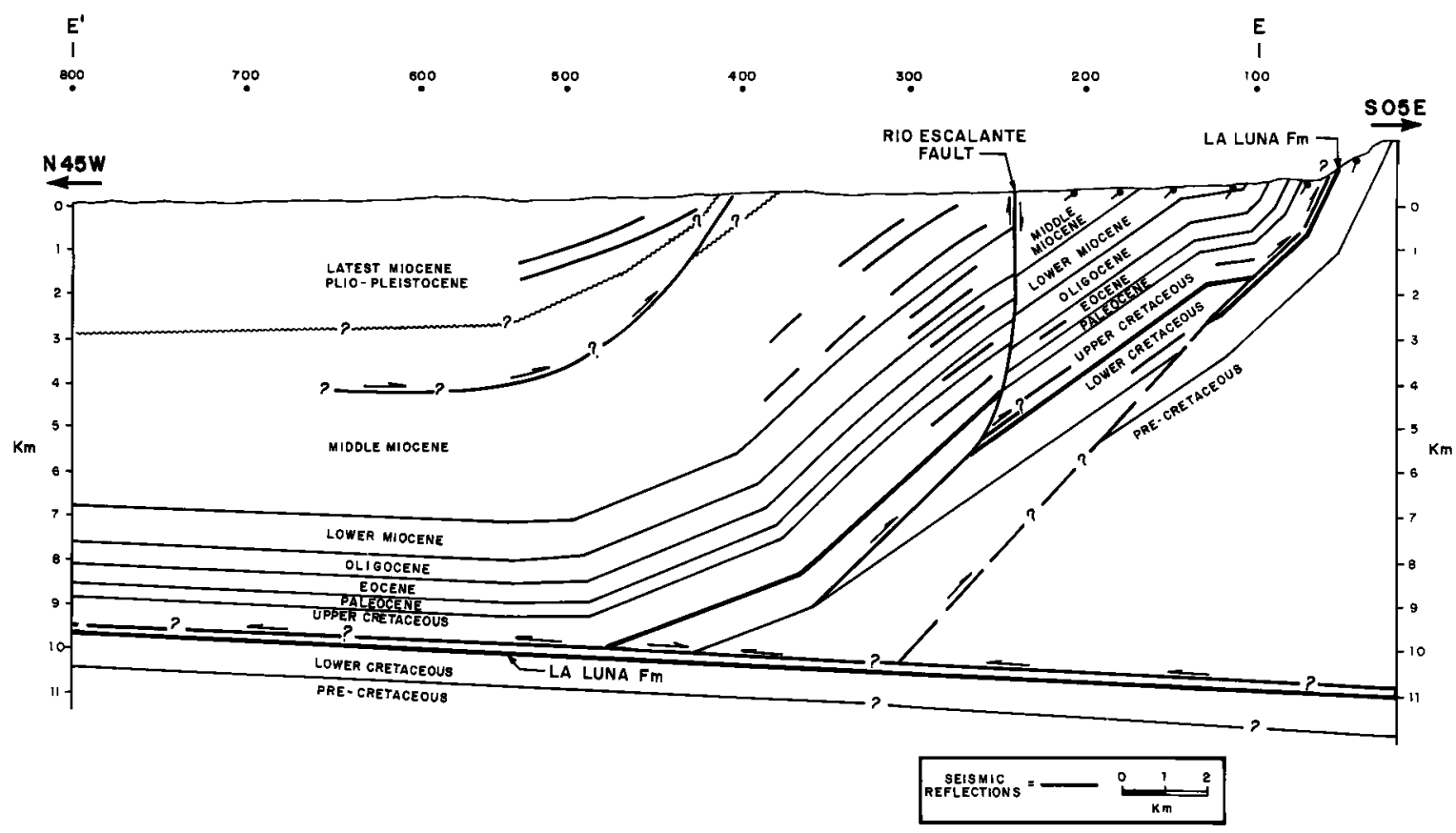

Fig. 16. Structural interpretation of section E-E'. The Rio Escalante fault is a backthrust with a trace oblique to the mountain front (Figure 2). The discordance of shallow reflectors at SP500 is interpreted as being produced by growth of the monocline.

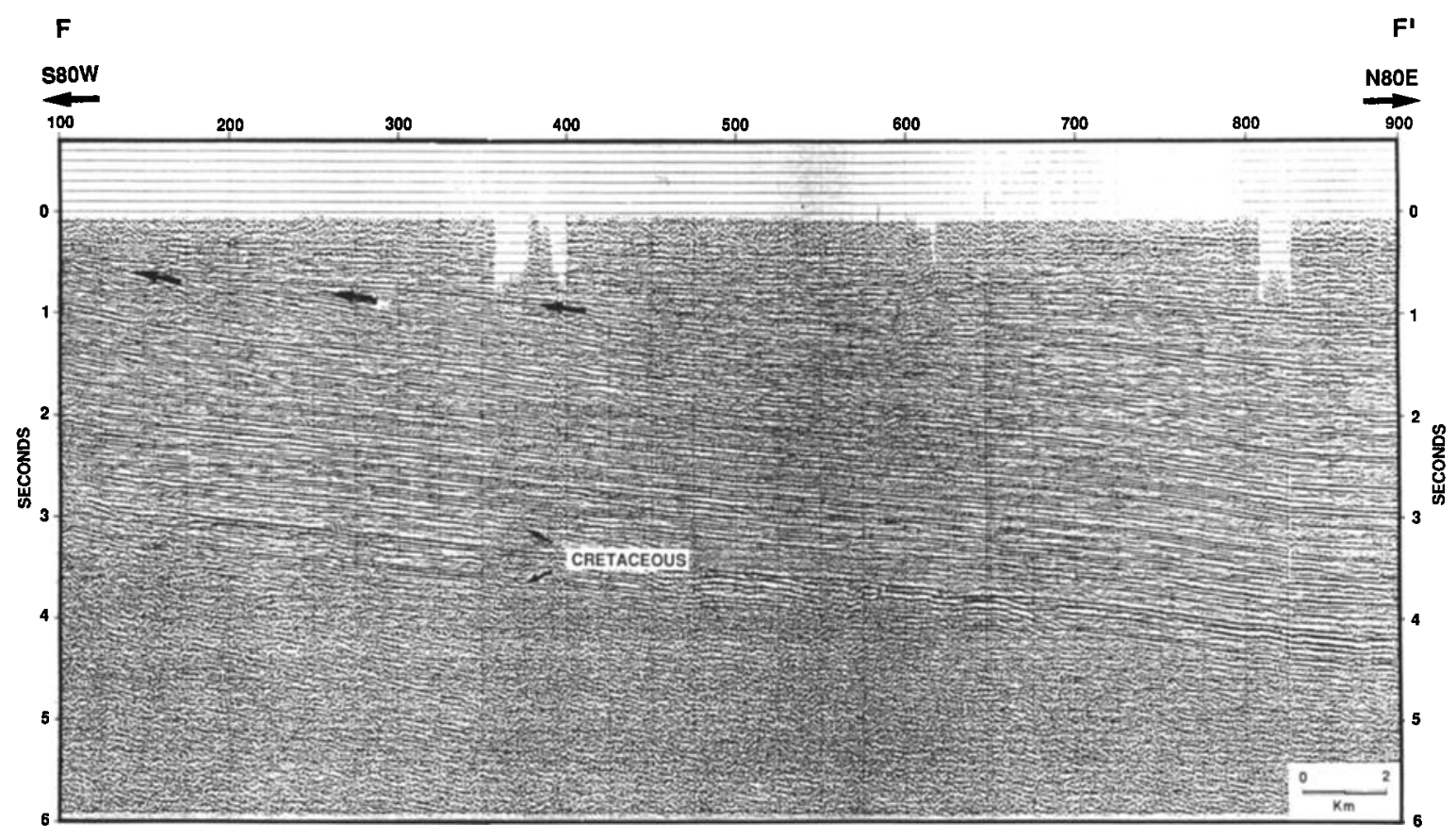

Fig. 17. Seismic line F-F' showing truncation of reflections (solid arrows) beneath the intramolasse unconformity. This unconformity is most pronounced in the western portion of the study area. 


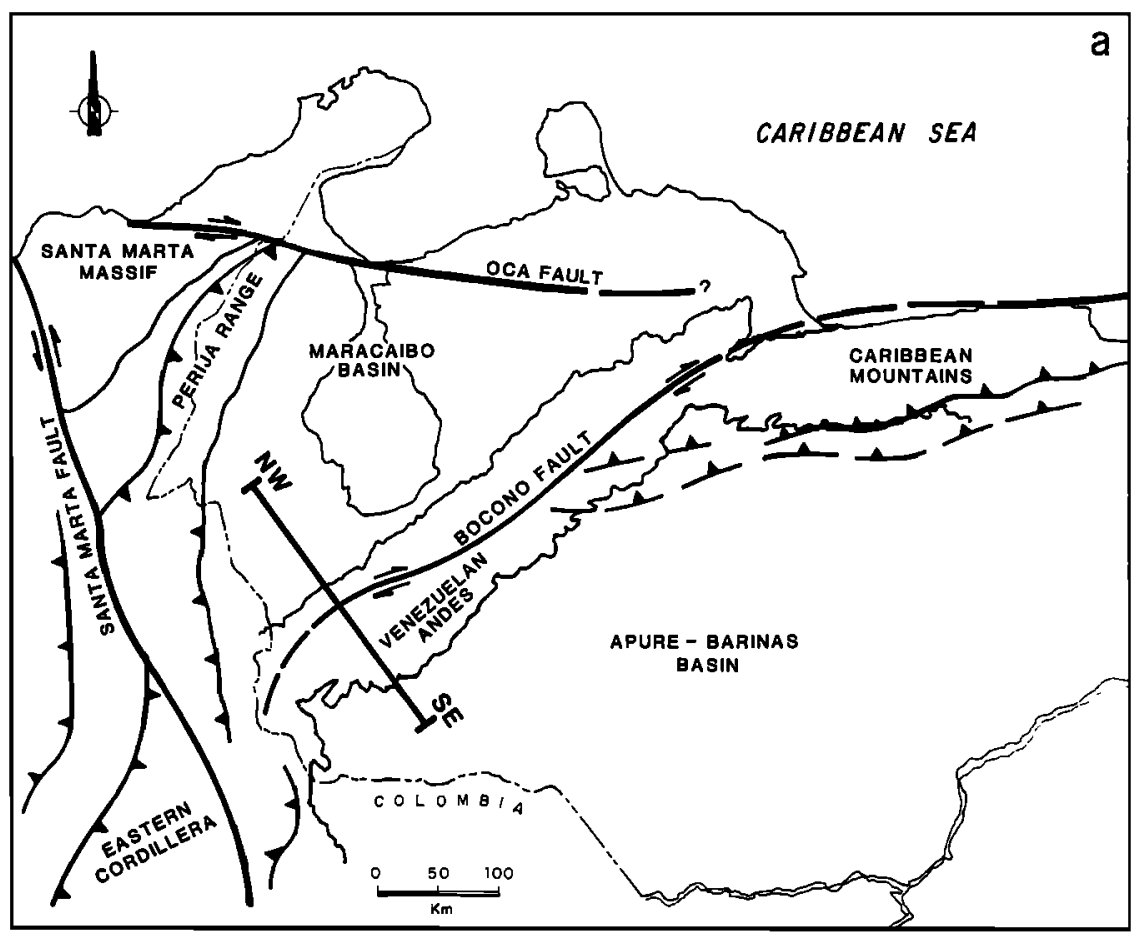

Fig. 18a. Tectonic location map for schematic cross section of the Venezuelan Andes (Figure 18b).

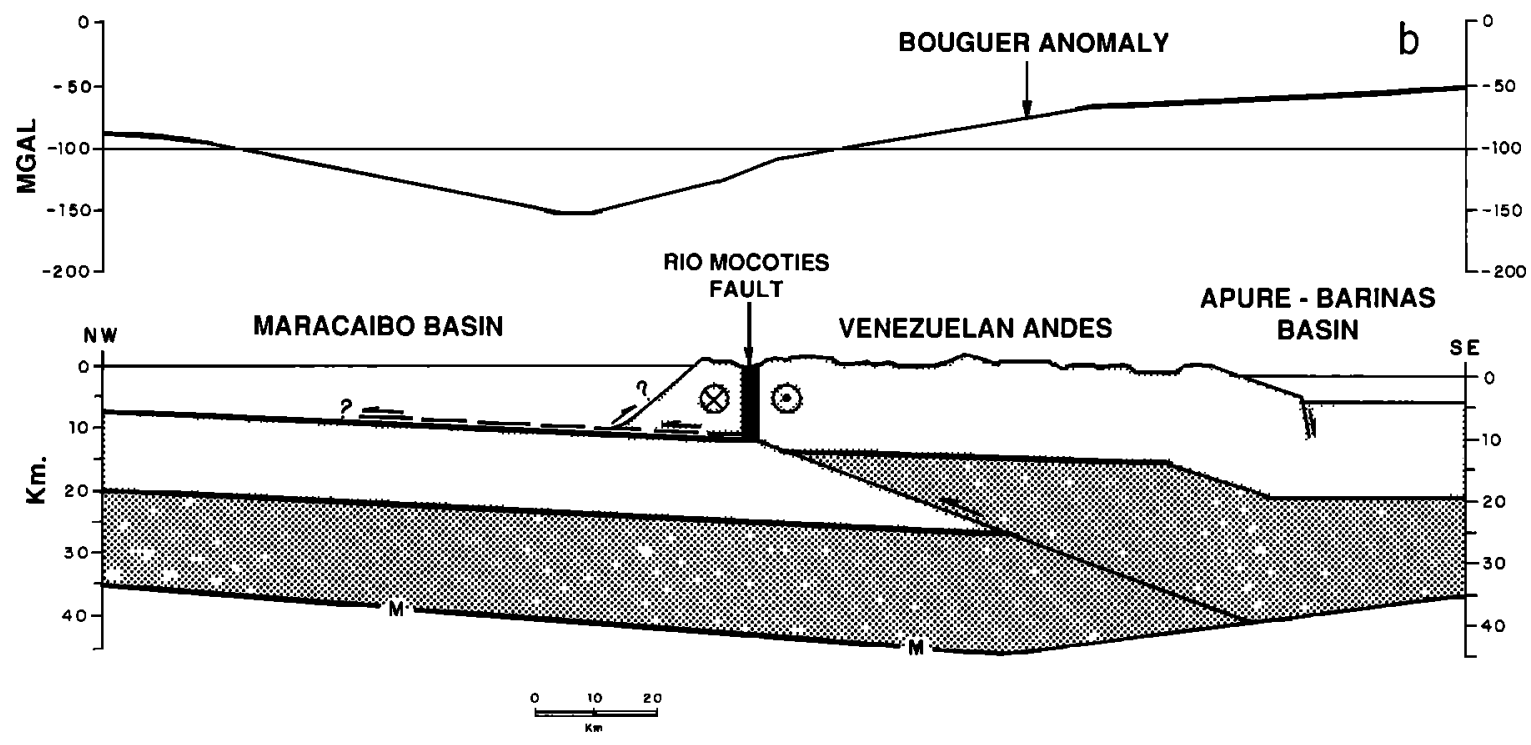

Fig. 18b. Schematic cross section of the Venezuelan Andes located in Figure 18a. We have interpreted the Venezuelan Andes as a fault bend fold structure deforming over a crustal-scale southeast dipping ramp. Estimates of the fault dip range from $20^{\circ}-25^{\circ}$ based on gravity models [Kellogg and Bonini, 1982, 1985] to about $27^{\circ}$ from fault bend fold theory for a $38^{\circ}$ frontal limb dip [Suppe, 1983]. In the solution shown ( $20^{\circ} \mathrm{ramp}$ ) the monocline on the southeastern flank of the Venezuelan Andes is the backlimb of the fault bend fold. The Andes are thrust 20-30 km northwestward toward the Maracaibo Basin. Vertical relief on the top of basement is more than $12 \mathrm{~km}$. Backthrusts in the monocline produce a wedge geometry and reduce the amount of blind slip required on the decollement northwest of the Venezuelan Andes. 
wedge geometry and reduce the amount of blind slip required on the decollement northwest of the Venezuelan Andes. Rock models of low-angle reverse faults deformed under confining pressure show late stage basement structures similar in shape to the predicted fault bend fold.

The monocline on the northwestern flank of the Venezuelan Andes is the result of crustal shortening in a northwestsoutheast direction. This shortening has been attributed to the convergence of the Caribbean plate and the North Andean microplate at the Caribbean marginal fault.

Two molasse cycles separated by an intra-Miocene discontinuity are present in the southwestern part of the foredeep basin. The first cycle corresponds to the Miocene EI Palmar and Isnotu formations. The second cycle corresponds to the late Miocene-Plio-Pleistocene Betijoque Formation. These thick (up to $8 \mathrm{~km}$ ) continental molasse deposits indicate that the Andean uplift had begun as early as early Miocene, although the formation of the monocline and the greatest uplift occurred in late Miocene to Pleistocene time. The intramolasse unconformity may be related to the initial late Miocene collision of the Panama volcanic arc with northwestem South America.

Acknowledgments. Christopher Kendall advised and directed all the stratigraphic aspects of the study. We thank Reginald Shagam and Wayne Narr for critical reviews. Maraven, S.A. Venezuela, generously provided all the seismic information. Albert Bally kindly provided a copy of Felipe Audemard's $\mathrm{Ph}$.D. thesis. The second author was supported in part by a grant from the Petroleum Research Fund of the American Chemical Society. We want to thank INTEVEP, S.A., Venezuela, for supporting research by the first author at the University of South Carolina and for authorizing the publication of this paper.

\section{REFERENCES}

Aggarwal, Y., Seismic slip rates and earthquake rupture zones in the southern Caribbean: implications for plate motions and earthquake hazard in this region, paper presented at 10 th Caribbean Geological Conference, Instituto Nacional de Investigaciones Geologico Mineras de Colombia, Cartagena, August 14-22, 1983.

Audebaud, E., et al., Les traits geologiques essentiels des Andes Centrales (PerouBolivie), Rev. Geogr. Phys. Geol. Dyn., 15, 73-114, 1973.

Audemard M. F., Tectonics of western Venezuela, Ph.D. thesis, 245 pp., Rice Univ., Houston, Tex., 1991.

Bellizia, A., N. Pimentel, and R. Bajo, Mapa geologico estructural de Venezuela, scale 1:500,000, Minist. de Minas e Hidrocarburos, Caracas, 1976.

Berg, R.R., Mountain flank thrusting in Rocky Mountain foreland, Wyoming and Colorado, Am. Assoc. Pet. Geol. Bull., 46, 2019-2032, 1962.

Berg, R.R., and F.E. Romberg, Gravity profile across the Wind River Mountains, Wyoming, Geol. Soc. Am. Bull., 77, 647-656, 1966.

Boesi, T., F. Galea, G. Rojas, M.A. Lorente, I. Duran, and M. Velasquez, Estudio estratigrafico del flanco Norandino, paper presented at Simposio Bolivariano, Exploracion Petrolera de las Cuencas Subandinas III, Sociedad Venezolana de Geologos, Caracas, March 13-16, 1988.

Bonini, W.E., C. P. de Gaeta, and V. Graterol, Mapa de anomalias gravimetricas de Bouguer de la parte norte de Venezuela y areas vecinas, scale 1:1,000,000, Minist. de Energ. y Minas, Dir. de Geol., Caracas, 1977.
Brown, W.G., Deformational style of Laramide uplifts in the Wyoming foreland, in Interaction of the Rocky Mountain Foreland and the Cordilleran Thrust Belt, edited by C.J. Schmidt and W.J. Perry, Jr., Mem. Geol. Soc. Am., 171, 1-25, 1988.

Bucher, W.H., Structure and orogenic history of Venezuela, Mem. Geol. Soc. Am., 49, 113 pp., 1952.

Burchfiel, B.C., and G.A. Davis, Nature and controls of Cordilleran orogenesis, western United States: Extensions of an earlier synthesis, Am. J. Sci., 275-A, 363-396, 1975.

Chester, J.S., J.H. Spang, and J.N. Logan, Comparison of thrust fault rock models to basement-cored folds in the Rocky Mountain foreland, in Interaction of the Rocky Mountain Foreland and the Cordilleran Thrust Belt, edited by C.J. Schmidt and W.J. Perry, Jr., Mem. Geol. Soc. Am., 171, 65-74, 1988.

Chigne, N.C., Aspectos relevantes en la exploracion de Apure, Mem. Congr. Geol. Venez. VI, 5, 2891-2929, 1985.

Coney, P.J., Plate tectonics and the Laramide orogeny, Spec. Publ. N. M. Geol. Soc., 6, 5-10, 1976.

Daniels, A.T., Stress and strain in the North Andes from earthquake data, M.S. thesis, 49 pp., Univ. of S. C., Columbia, 1991.

DeMets, C., R.G. Gordon, D.F. Argus, and S. Stein, Current plate motions, Geophys. J. Int., 101, 425-478, 1990.

Deratmiroff, G.N., Late Cenozoic imbricate thrusting in Venezuelan Andes, Am. Assoc. Pet. Geol. Bull., 55, 1336-1355, 1971.

De Toni, B., Seismic reflection interpretation and hydrocarbon prospectivity of the northwestem flank of the Venezuelan Andes and the southem plains of the Maracaibo Basin, M.S. thesis, 118 pp., Univ. of S. C., Columbia, 1990.

Dewey, J.W., Seismicity and tectonics of westem Venezuela, Bull. Seismol. Soc. Am., 62, 1711-1751, 1972.

Dickinson, W.R., and W.S. Snyder, Plate tectonics of the Laramide orogeny, in Laramide Folding Associated with Basement Block Faulting in the Westem United States, edited by V. Matthews, Mem. Geol. Soc. Am., 151, 35-366, 1978.

Elam, J.G., The tectonic style in the Permian basin and its relationship to cyclicity, in Cyclic Sedimentation in the Permian Basin, Publ. West Tex. Geol. Soc., 69-56, 55-79, 1969.

Eva, A.N., K. Burke, P. Mann, and G. Wadge, Four-phase tectonostratigraphic development of the Southern Caribbean, Mar. Pet. Geol., 6, 9-21, 1989.

Fichter, H.J.K., Tectonics of southern Oklahoma, Okla. Geol. Rep. 591, Shell Oil, Tulsa, Okla. 1954.

Giegengack, R., Late Cenozoic tectonic environments of the Central Andes, Mem. Geol. Soc. Am., 162, 343-364, 1984.

Gonzalez de Juana, C., Introduccion al estudio de la geologia de Venezuela, Bol. Geol. Venez. Dir. Geol., 2, 407-416, 1952.

Gonzalez de Juana, C., J. Arozena, and X.C. Picard, Geologia de Venezuela y de Sus Cuencas Petroliferas, 1031 pp., Foninves, Caracas, 1980.

Hargraves, R.B., and R. Shagam, Paleomagnetic study of La Quinta Formation, Venezuela, Am. Assoc. Pet. Geol. Bull., 53, 537-552, 1969. 
Hospers, J., and J.C. Van Wijnen, The gravity field of the Venezuelan Andes and adjacent basins, Versl. Gewone Vergad. Afd. Natuurkd. K. Ned. Akad. Wet., 23, 1 95, 1959.

Howard, J.H., Structural development of the Williams Range thrust, Colorado, Geol. Soc. Am. Bull., 77, 1247-1264, 1966.

Jordan, T.E., and R.W. Allmendinger, The Sierras Pampeanas of Argentina: A modern analogue of Laramide deformation, Am. J. Sci., 286, 737-764, 1986.

Jordan, T.E., B.L. Isacks, R.W. Allmendinger, J.A. Brewer, V.A. Ramos, and C.J. Ando, Andean tectonics related to geometry of subducted Nazca plate, Geol. Soc. Am. Bull., 94, 341-361. 1983

Jordan, T.H., The present-day motions of the Caribbean Plate, J. Geophys. Res. 80, 4433-4439, 1975.

Kellogg. J.N., Cenozoic tectonic history of the Sierra de Perija, Venezuela-Colombia, and adjacent basins, in Caribbean-South American Plate Boundary and Regional Tectonics, edited by W.E. Bonini, R.B. Hargraves, and R. Shagam, Mem. Geol. Soc. Am., 162, 239-261, 1984.

Kellogg, J.N., and W.E. Bonini, Subduction of the Caribbean plate and basement uplifts in the overriding South American plate, Tectonics, 1, 251-276, 1982.

Kellogg, J.N., and W.E. Bonini, Reply, Tectonics, 4, 785-790, 1985.

Kellogg, J.N., I.J. Ogujiofor, and D.R. Kansakar, Cenozoic tectonics of the Panama and the North Andes blocks, Proc. Lat. Am. Geol. Congr. VI, 1, 4059, 1985.

Kelly, V.C., Monoclines of the Colorado Plateau, Geol. Soc. Am. Bull., 66, 789. 804, 1955.

Kohn, B.P., R. Shagam, P.O. Banks, and L.A. Burkley, Mesozoic-Pleistocene fission-track ages on rocks of the Venezuelan Andes and their tectonic implications, Mem. Geol. Soc. Am., 162, 365-384, 1984.

Ladd, J.W., M. Truchan, M. Talwani, P.L Stoffa, P. Buhl, R. Houtz, A. Mauffret, and $G$. Westbrook, Seismic reflection profiles across the southem margin of the Caribbean, in Caribbean-South American Plate Boundary and Regional Tectonics, edited by W.E. Bonini, R.B. Hargraves, and R. Shagam, Mem. Geol. Soc. Am., 162, 153-159, 1984.

Lehner, P., H. Doust, G. Bakker, P.
Allenbach, and J. Gueneau, Active margins-Caribbean margin of South America, profiles C-1422, C-1412, and C-1413, in Seismic Expression of Structural Styles, edited by A.W. Bally, AAPG Stud. Geol. 15(3),

3.4.2-111 to 3.4.2-128, 1983.

Lipman, P.W., H.J. Prostka, and R.L. Christiansen. Evolving subduction zones in the western United States as inferred from igneous rocks, Science, 175, 821825, 1971.

Lotze, F., Das Problem der "saxonischen Faltung," Geotekton. Forsch., 3, 73-84, 1938.

Macellari, C., Late Tertiary tectonic history of the Tachira Depression, south western Venezuelan Andes, in Caribbean-South American Plate Boundary and Regional Tectonics, edited by W.E. Bonini, R.B. Hargraves, and R. Shagam, Mem. Geol. Soc. Am., 162, 333-341, 1984.

Mann, P., and K. Burke, Neotectonics of the Caribbean, Rev. Geophys., 22, 309. $362,1984$.

Matthews, V., III, Ed., Laramide folding associated with basement block faulting in the western United States, Mem. Geol. Soc. Amer., 151, 370 pp., 1978.

Meier, B., M. Schwander, and H.P. Laubscher, The tectonics of Táchira: $\mathrm{A}$ sample of North Andean tectonics, in The Anatomy of Mountain Ranges, edited by J.P. Schaer and J. Rogers, pp. 229-237, Princeton University Press, Princeton, N.J., 1987.

Minster, J.B., and T.H. Jordan, Present-day plate motions, J. Geophys. Res., 83, 5331-5354, 1978.

Monsalve, O., Estilo tectonico del flanco Norandino de Venezuela (Afiche-Poster), paper presented at Simposio Bolivariano, Exploracion Petrolera de las Cuencas Subandinas III, Sociedad Venezolana de Geologos, Caracas, March 13-16, 1988.

Narr, W., Deformation of basement in basement-involved, compressive structures, in Laramide Basement Deformation in the Rocky Mountain Foreland of the Westem United States, edited by C.J. Schmidt, R. Chase, and E. Erslev, Spec. Pap. Geol. Soc. Am., 280, in press, 1993.

Pennington, W.D., Subduction of eastem Panama Basin and seismotectonics of northwestern South America, $J$. Geophys. Res., 86, 10,753-10,770, 1981.

Prucha, J.J., J.A. Graham, and R.P.
Nickelsen, Basement-controlled deformation in Wyoming province of Rocky Mountains foreland, Am. Assoc. Pet. Geol. Bull., 49, 966-992, 1965.

Rod, E., Comments on The gravity field of the Venezuelan Andes and adjacent basins by J. Hospers and J.C. Vanwijner, Bol. Inf. Asoc. Venez. Geol. Min. Pet., 3, 170-175, 1960.

Schubert, C., Late-Cenozoic pull-apart basins, Boconó fault zone, Venezuelan Andes, J. Struct. Geol., 2, 463-468, 1980.

Schubert, C., Neotectonics of the Bocono Fault, western Venezuela,

Tectonophysics, 85, 205-220, 1982.

Schubert, C., Comments on "Subduction of the Caribbean plate and basement uplifts in the overriding South American plate" by J.N. Kellogg and W.E. Bonini, Tectonics, 4, 781-783, 1985.

Shagam, R., Evolucion tectonica de los Andes Venezolanos, Mem. Congr. Geol. Venez. $N$, 2, 1201-1258, 1972.

Smithson, S.B., J. Brewer, S. Kaufman, J. Oliver, and D. Hurich, Nature of Wind River Thrust, Wyoming, from COCORP deep-reflection data and from gravity data, Geology, 6, 648-652, 1978.

Stearns, D.W., Mechanisms of drape folding in the Wyoming Province, Wyo. Geol. Assoc. 23rd. Annu. Field Conf., Guideb., 125-143, 1971.

Steams, D.W., and D.M. Weinberg, A comparison of experimentally created and naturally formed drape folds, Wyo. Geol. Assoc. 27th Annu. Field Conf., Guideb., 159-166, 1975.

Stephan, J.F., Una interpretacion de los complejos con bloques asociados a los flyschs Paleoceno-Eoceno de la Cadena Caribe: El emplazamiento submarino de la Napa de Lara, paper presented at 8th Caribbean Geological Conference, Willemstad, Curacao, July 9-24, 1977.

Stille, H., Mitteldeutsche Rahmenfaltung, Jahresber. Niedersachs. Geol. Ver., 3 , 141-169, 1910.

Stille, $H$., The upthrust of salt masses of Germany, Am. Assoc. Pet. Geol. Bull., 9, 417-441, 1925.

Suppe, J., Geometry and kinematics of fault-bend folding, Am. J. Sci., 283, 684-721, 1983.

Tearpock, D.J., and R.E. Bischke, Applied Subsurface Geological Mapping, 648 pp, Prentice-Hall, Englewood Cliffs, N. J., 1991.

Toto, E.A., and J.N. Kellogg, Structure of the North Colombia fold belt-An active 
accretionary prism, J. S. Am. Earth Sci., 5(2), 211-222, 1992.

Vega, V., J.N. Kellogg, and J.T.

Freymueller, Relative motions of South America, the Caribbean and Panama determined by CASA GPS geodetic measurements, Eos Trans. AGU, 72 (44), Fall Meeting Suppl., 115, 1991.

White, C., Patron estructural y prospectividad del frente Norandino entre
La Fria y El Vigia, Mem. Congr. Geol. Venez. VI, 8, 5397-5418, 1985.

Wise, D.U., Keystone faulting and gravity sliding driven by basement uplift of $\mathrm{Owl}$ Creek Mountains, Wyoming, Am. Assoc. Pet. Geol. Bull., 47, 586-598, 1963.

B. De Toni, INTEVEP, S.A., Apartado 76343, Caracas 1070-A, Venezuela.
J. Kellogg, Department of Geological Sciences, University of South Carolina, Columbia, SC 29208.

(Received May 28, 1992; revised June 29, 1993; accepted July 13, 1993.) 